\title{
PHYTOSANITARY CONDITION OF SPRING BARLEY CROPS UNDER THE INFLUENCE OF MICROBIAL PREPARATION MICROHUMIN AND DIFFERENT FERTILIZING SYSTEMS
}

\author{
O. P. Tymoshenko, O. P. Lepekha
}

Spring barley is a valuable feeding, technical, cereal and brewing culture that is the second crop in Ukraine after winter wheat for economic value. In Ukraine 3-4 million ha of spring barley and 400-500 thousand ha of winter barley is planted annually. However, the crop yield is low. One reason for the shortfall of gross grain harvest and significant reduction in its quality is lesion of plants with infectious diseases. The most common of them are powdery mildew, striped and net blotch, leaf rust, root rots, rhynchosporium infection, etc. [1]. In areas of Woodlands and Forest-steppe of Ukraine the development of diseases on the susceptible varieties of spring barley annually reaches $85 \%$ [2].

Application of fertilizers belongs to agricultural practices on which phytosanitary status of crops largely depends. When fertilizers are applied in the soil physical and chemical properties are changed that influence the development of pathogens and their antagonists [3]. S. F. Buha [4], summarizing data on physiological and biochemical alterations in plants by the action of root nutrition elements, argues that fertilizers affect the intensity of lesion of barley plants with diseases. Fertilization systems may have preventive and therapeutic effect on the pathological process in plants, changing relationships in "plant - host pathogen" system.

Along with the use of fertilizers to increase yields and improve product quality of crops microbial preparations have been increasingly used in recent years [5]. However, no systematic studies of their effect on phytosanitary condition of agricultural crops under different fertilization systems (incl. organic) were conducted, which determines the relevance of our study.

Materials and methods. The study was conducted in 2012-2014 in the stationary field experiment (founded in 2010) of the Institute of Agricultural Microbiology and Agroindustrial Manufacture of NAAS with short crop rotation (potato - barley - pea - winter wheat) on the leached black soil containing $2.12 \%$ of humus; $95.2 \mathrm{mg}$ of slightly hydrolyzed nitrogen per kilogram of soil; movable forms of phosphorus $\left(\mathrm{P}_{2} \mathrm{O}_{5}\right)-$ $168 \mathrm{mg} / \mathrm{kg}$ of soil (by Kyrsanov), the content of exchangeable potassium $\left(\mathrm{K}_{2} \mathrm{O}\right)$ (by Kyrsanov) $-58 \mathrm{mg} / \mathrm{kg}$ of soil; $\mathrm{pH}_{\text {salt }}-5.30$.

The scheme of the experiment with spring barley of Hosya variety provided the following variants:

1 - without fertilizers (control);

2 - in the first year the after action of $40 \mathrm{t} / \mathrm{ha}$ of manure (applied once per rotation under potatoes);

$$
\begin{aligned}
& 3-\mathrm{N}_{30} \mathrm{P}_{30} \mathrm{~K}_{30} ; \\
& 4-\mathrm{N}_{60} \mathrm{P}_{60} \mathrm{~K}_{60} ; \\
& 5-\mathrm{N}_{90} \mathrm{P}_{90} \mathrm{~K}_{90} \\
& 6 \text { - in the first year the after action of }
\end{aligned}
$$
$40 \mathrm{t} /$ ha of manure $+\mathrm{N}_{30} \mathrm{P}_{30} \mathrm{~K}_{30}$;

7-12 - the same including preplant seed bacterization with microbial preparation Microhumin (TU U 24.1-00497360007:2009).

The area of experimental plot was 86.4 $\mathrm{m}^{2}$, repetition of the experiment - quadruple. Agricultural technology of spring barley growing is common for the areas of Wodlands. The bacterization of spring barley seeds was carried out according to SOU 01.11-37-782 [6].

Diseases of roots and leaves on the plants of spring barley were discovered and described by the external manifestation of symptoms according to the atlas and determinants of diseases of crops $[1 ; 7]$. Records of distribution $(\mathrm{P})$ and the degree of development $(\mathrm{R})$ of root rots in spring barley plants were carried out in the phases of tillering, stem elongation and milky stage. The diseases of leaves of spring barley were calculated by lesion intensity scales during the maximum of their display - in the phase of flowering and milky stage [8]. Statistical analysis of the experimental data was performed using the dispersion method [9].

Thus, during the use of organic fertilizer system the decrease in the spread of 
root rots of spring barley is observed by 4.5 $21.0 \%$, and the development of plant diseases - by $0.2-4.0 \%$. At the background of mineral fertilizer the decrease in the spread of plant diseases is recorded, especially at the fertilization with the dose $\mathrm{N}_{60} \mathrm{P}_{60} \mathrm{~K}_{60}$. Influenced by Microhumin, the level of lesion of plants with root rots significantly decreased in all systems of fertilization.

The development of rhynchosporium infection reduced on the leaves of spring barley at the use of organic fertilizers. At the same time, the development of powdery mildew and dark brown blotch on fertilized agricultural backgrounds increased especially with the increase of the doses of fertilizers. Microbial preparation Microhumin in the combined use with organic and mineral fertilizers contributed to the improvement of phytosanitary condition of crops of spring barley of Hosya variety. 